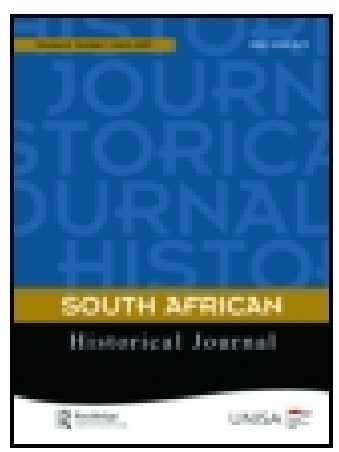

South African Historical Journal

\title{
Caste, Class and Race: Continuities and Discontinuities across Indian and South African Schools
}

\section{Crain Soudien}

To cite this article: Crain Soudien (2007) Caste, Class and Race: Continuities and Discontinuities across Indian and South African Schools, South African Historical Journal, 57:1, 113-133, DOI: $10.1080 / 02582470709464712$

To link to this article: http://dx.doi.org/10.1080/02582470709464712

曲 Published online: 25 Mar 2009.

Submit your article to this journal $₫$

Џll Article views: 106

Q View related articles $\sqsubset$ 
South African Historical Journal, 57 (2007), 113-133

\title{
Caste, Class and Race: \\ Continuities and Discontinuities across Indian and South African Schools
}

\author{
CRAIN SOUDIEN \\ University of Cape Town
}

\section{INTRODUCTION}

This essay is based on a study conducted from 2002 to 2004, Inclusion and Exclusion in Indian and South African Schools (Inexsa), ${ }^{1}$ which sought to explore processes of inclusion/exclusion at community and school levels in selected schools in India and South Africa. This examination entailed a focus on race in the South African context and on caste in the Indian setting.

A dimension of the study that I wish to explore here, reading the data, concerns the amenability of the policy platform in both countries for dominant class reappropriation, or, in other words, how the policy is able to be used by dominant groups to recover their social advantage. I look at the forms this reappropriation takes in the two contexts and ask what this might tell us about their policy trajectories. Important about the discussion are the policy similarities and dissimilarities that arise in these two contexts in the course of attempting to develop an inclusionary social welfare platform. Also important in stating this objective is that it is not so much the notions of race and caste, and their similarity, that hold the discussion together but the social interventions with respect to these

1. See, inter alia, R. Subrahmanian, 'Introduction: Exploring Processes of Marginalisation and Inclusion in Education', IDS Bulletin, 34, 1 (2003), 1-8, and Y. Sayed, R. Subrahmanian, C. Soudien, S. Balagopalan and N. Carrim, Education Exclusion and Inclusion: Policy and Implementation in India and South Africa (London, forthcoming). In writing this article I am heavily indebted to my colleagues on this project, Sayed, Subrahmanian, Balagopalan and Carrim. The interpretation I generate here, with all its shortcomings, however, is my own responsibility for which they must not be required to take any blame.

2. The ambit of this discussion has, of course, long been a subject of fascination in the Englishspeaking world. The classic work of O. Cox, Caste, Class and Race (New York, 1970), first published in 1948, remains an important attempt to engage with the relevance of caste for understanding modern racism. In the South African context, the work of No Sizwe, One Azania, One Nation: The National Question in South Africa (London, 1979) (No Sizwe being the pseudonym used by Neville Alexander), continues in the tradition of Cox and is among the most important sociological and historical attempts to show the caste-like nature of race in the continued hierarchisation of race in the country. 
on the part of the state. What is it about these interventions and their trajectories in these two countries that we need to take note of?

In attempting to answer this question, I have structured the article into two parts. Part One begins with a short theoretical interjection and a quick review of race and caste for the purposes of demonstrating the issues that confront the South African and Indian states. This discussion is followed by a description of the two states' broad commitments to educational inclusion and the challenges that relate to these. Part Two follows with a description of the Inexsa study and its findings. Central to this component of the article is a review of experiences in the two systems and their schools and an attempt to distil from these an understanding of how the commitments of the state are adjusted and/or deformed in each country.

\section{PART ONE}

\section{Two Politics of Difference}

In reading the trajectories noted above, the theoretical framework that holds the analysis in place essentially emerges from a critical reading of the concept of inclusion. The work of $\mathrm{McCarthy}^{3}$ is crucial here. Inclusion, as an idea, is invariably projected in strongly normative terms: inclusion by definition is good and exclusion, conversely, bad. The point of an inclusion policy, thus, is to overcome exclusion: the triumph of the good over the bad. Important as stances such as these are, they ignore the possibility that inclusive policies may themselves result in new forms of exclusion. How this arises, and it is crucial for the direction the discussion takes in this article, has a great deal to do with the ways in which social virtues such as education work both as the means for social mobility and access, on the one hand, and as the means through which social selection and differentiation, on the other, take place. Education includes inasmuch as it excludes. Second, processes of inclusion generally take their dynamic from a form of 'normalisation' in which groups, be they kinship groups, classes, structures or whatever, define and constitute themselves (socially) in their 'ideal' forms. Relative to them other communities, groups and individuals are identified and invariably positioned in negative ways. Out of this, among other things, the perception is generated, and indeed the reality arises, that certain groups lack access or entitlements to certain rights and services. Hence, as a consequence, such groups, communities and individuals, when ameliorative initiatives on the part of dominant groups take shape, become the target for special inclusive measures to overcome their exclusion. Difficult about such approaches is that they often ignore the existing and complex social relations in society in which these restorative or

3. C. McCarthy, 'Nonsynchrony and Social Difference: An Alternative to Current Radical Accounts of Race and Schooling', in A.H. Halsey, H. Lauder, P. Brown, S.P. Stuart and A. Wells, eds, Education, Culture, Economy, Society (Oxford, 1997), 541-56. 
redress initiatives are given expression. The consequence is that in privileging particular groups, or segments of groups, other dynamics that lie latent or continue to operate both within and between all the players in the society are catalysed and produce new challenges, including the possibility of new inequities. Third, the concept underestimates differences (and similarities) - race, caste, class, gender and so on - between and within groups, communities and individuals, in that it ignores the context-specific dynamics which influence who should be included or excluded. In terms of these differences and similarities, the discourse of educational exclusion and inclusion, fourthly, fails to specify the relationships between race, class, gender, and indeed other forms of difference and inequity in society, and to show how these articulate with each other. ${ }^{4}$

Both India and South Africa as states, and their scholars, it needs to be said, have made these issues the subject of intense discussion. ${ }^{5}$ Both countries have enriched the global discussion of these issues with important insights. ${ }^{6}$ Major conceptual and representational difficulties, however, continue to plague the discussions in both countries. Towards understanding what these are, it is important to explain the ideological grip that race in South Africa and caste in India continue to exercise over the social landscape and the complex ways in which these condition the inclusionary projects in the two countries.

Race, predictably, remains the dominant factor in South African social policy and analysis. Its centrality arises out of the country's more than 350-year experience of contact between a white settler and a black indigenous population and an accompanying conflict in which racism played an important part. In the course of the unfolding history of these relationships, a particular language of racial description developed which, in the last hundred years, has come to settle around the identification of groups described as African, coloured, white and Indian. The policy of the apartheid government was to separate groups racially with respect to their housing, health, education and other social rights. African people, treated more prejudicially than coloureds and Indians, had their citizenship rights removed in what was regarded as white South Africa. Their political destinies were expected to be fulfilled in independent homelands. The term 'black'

4. See M. Apple and L. Weis, eds, Ideology and Practice in Schooling (Philadelphia, 1983), M. Sarup, The Politics of Multi-Racial Education (London, 1986) and McCarthy, 'Nonsynchrony'.

5. See P. Chatterjee, A Possible India (New Delhi, 1997); P. Chatterjee, 'The Nation and its Women', in R. Guha, ed., A Subaltern Studies Reader, 1986-1995 (New Delhi, 2001); R. Guha, ed., A Subaltern Studies Reader, 1986-1995 (New Delhi, 2001); R. Bharucha, The Politics of Cultural Practice: Thinking through Theatre in an Age of Globalization (New Delhi, 2001); $\mathbf{H}$. Wolpe, Race, Class and the Apartheid State (Paris, 1988); N. Alexander, An Ordinary Country: Issues in the Transition from Apartheid to Democracy in South Africa (Scottsville, 2002); I. Mandaza, Race, Colour and Class in Southern Africa (Harare, 1997); and M. MacDonald, Why Race Matters in South Africa (Scottsville, 2006). This list, of course, barely touches the surface of this complex literature.

6. See the subaltern discussion in India and the race and class neo-Marxist recovery of history in South Africa. 
came into prominence in the apartheid era as part of a political movement to counter the deficit-laden term 'non-white' and included people classified African, Indian and coloured.

Caste in India refers to the social categories, often based on occupations, which emerged out of its Hindu past in terms of which people came to be located in a hierarchy of positions. This resulted in inequitable outcomes for those groups considered 'untouchable' (Dalits to include those within 'scheduled castes' and Adivasis to describe 'tribal groups') and those clustered at the bottom of the social hierarchy described in the somewhat problematic term 'other backward castes'. The term 'Scheduled Caste' is used to denote (in a legal sense) 'ex-untouchable' castes based on a Schedule promulgated by the British in 1936. This Schedule consisted of a list of castes that were entitled to special educational benefits, parliamentary seats and public employment. ${ }^{7}$

While race remains the most visible vector for the constitution of difference in South Africa, and continues to dominate public discourse, debate about its nature and structure has been intense. ${ }^{8}$ One of the most important scholars of social difference in South Africa, Harold Wolpe, ${ }^{9}$ argues that neither race nor class, by themselves, is capable of explaining the nature of the South African social formation and the ways in which privilege, power and position are distributed. Neither is able to grasp the entire story of social division, the hierarchies that operate within society and, critically, how rights accrue or are denied. Explaining South Africa and seeking to resolve the injustices and inequalities would require more than working through race and/or class. In his work he makes the crucial point that the formation and maintenance of racial groups and division in South Africa is a process that takes place in specific contexts that are subject to both centrifugal and centripetal pressures. Allied to these is the crucial element of politics, which operates often independently from other factors but always in some form of articulation with them. This combination of the instances of race, class and politics produces effects and outcomes that are, moreover, ongoing and always in flux. They produce differentiations within groups, fracturing their homogeneity. Privileging race therefore as a category of analysis underplays the ways in which a whole range of conditions and processes influence the sense of cohesiveness and fragmentation within groups. Class analysis too, he continues to argue, suffers from a similar insularity and reductionism. As a result of this reductionism, little room is allowed for non-class effects. 'It is clear', says Wolpe, 'that this analysis

7. O. Mendelsohn and M. Vicziany, The Untouchables: Subordination, Poverty and the State in Modern India (Cambridge, 1998).

8. See H. Adam, Modernizing Racial Domination: The Dynamics of South African Politics (Berkeley, 1971); E. Boonzaaier, "Race" and the Race Paradigm', in E. Boonzaaier and J. Sharp, eds, South African Keywords: The Uses and Abuses of Political Concepts (Cape Town, 1988); S. Marks and S. Trapido, 'The Politics of Race, Class and Nationalism', in S. Marks and S. Trapido, eds, The Politics of Race, Class and Nationalism in Twentieth Century South Africa (London, 1987); Wolpe, Race, Class; Alexander, An Ordinary Country.

9. Wolpe, Race, Class. 
provides no conceptual basis for an analysis of the specific conditions in which racial categorisations come to provide the content of class struggles and/or the basis of organisation of interests in a manner which both cuts across class divisions and yet may serve to sustain, change (for example, racialisation or deracialisation) or undermine them'. ${ }^{10}$

The value of Wolpe's work is that it calls into question the ways in which discourses of race and class have been mobilised to understand South Africa. In his text Race, class and the apartheid state, he implicitly argues against the dominant iconographic systems of South Africa, particularly those of race, and looks to more complex ways of understanding social difference in South Africa. While this analysis can be said to underplay the complex ways in which gender has been instantiated into social differentiation in South Africa, it provides a framework within which a multiplicity of social factors can be brought into play in understanding the nature of South African society. In attempting to analyse post-apartheid South Africa there is much to work with here, therefore, because while it remains the case that the essential system of referencing and marking difference remains primarily marked by race, a critical analysis of the society will show how other factors have come to rearticulate or redefine the character of race.

Like race in South Africa, caste in India remains, of necessity, high on the political and social agenda. Despite almost a hundred years of social engineering, beginning with attempts in the princely states of Mysore and Kolhapur to institute a practice of job reservation for lower castes and minorities, caste discrimination has not only endured, but, paradoxically, has also remained a durable site for the production of social identity. ${ }^{11}$ While its articulation with class has produced a much less legible social landscape, ${ }^{12}$ it clearly continues to vex both policy makers and social analysts. The current debate around it reflects the state of confusion in the country around the impact of recent (the last fifty years) policy efforts to mitigate its worst effects. Questions are being asked, as a result, in the context of its apparent dilution, whether it remains a valid category of analysis. Does not, it is suggested, economic inequality provide a better description for the discrimination experienced in India today? When we discern discrimination, should the category of focus be class or caste? In attempting to make sense of these difficulties, commentators such as Oomen ${ }^{13}$ suggest that within the "multiple deprivations' experienced by lower-caste people - social, economic, and political - there is great variation among the 400 major Scheduled Castes in terms of economic and social status, and that within castes there are rural-urban and gender disparities. Clear, however, when all these variations are taken into account, is the persistence of endemic poverty and low social status across all the Scheduled

10. Ibid., 15 .

11. See http://en.wikipedia.org/wiki/Affirmative Action.

12. See Chatterjee, $A$ Possible India.

13. T.K. Oomen, State and Society in India: Studies in Nation-Building (Newbury Park, California, 1990). 
Castes. While poverty may be understood as an outcome of a community's position in the economic system and access to resources, these factors are linked to social status and both are in turn the products of their overdetermined history. It is for this reason that it remains critical to look at the position of specific communities in the local economy (that is, occupation, land ownership, access to resources and markets) and at the ways in which caste position or community norms structure social location. ${ }^{14}$

A further important reason for retaining caste as a focus of analysis is the rise of Dalit movements, whose intellectual leadership has been vocal in appropriating this subordinate identity as a means of mobilisation. ${ }^{15}$ In terms of this, caution is required in interpreting the experience of lower-caste groups, precisely because the experience of living as low-caste groups in a hierarchical society has provided Dalits with a sense of the specificity of their own identity. ${ }^{16}$ While the discussion has interesting correlates with the retention of race in redress initiatives in South Africa, it is important to recognise the distinct politics at play in the Indian context. The rejection of caste oppression is not the same as the rejection of caste as a way of understanding the different social rules that inform the everyday life of different social groups. While an immobilising and even demobilising impetus is traditionally attributed to caste, in terms of the ways it fixes the identity of groups, restricts occupational and educational mobility, and imposes residential and resource limitations on people, and thus has been identified as a real source of oppression, at the same time it has made available to people a sense of identity which they have

14. Sayed et al., Inclusion and Exclusion. The vast majority of Dalits (about 81 per cent) reside in rural areas and are employed in the agricultural economy (about three-fourths). According to the 1991 Census, almost half of Scheduled Caste 'main workers' were listed as agricultural labourers, followed by cultivators at 25 per cent. Only 9,8 per cent were in the secondary sector, including manufacturing (this would include artisanal leather work), and 13 per cent in the tertiary sector: see Mendelsohn and Vicziany, The Untouchables. However, their status with regard to agricultural land ownership is poor: in 1992, 13 per cent of SCs were landless and 73 per cent had marginal holdings, compared to 10 and 54 per cent for other castes, respectively: S. Thorat and R. Deshpande Thorat, 'Caste System and Economic Inequality: Economic Theory and Evidence', in G. Shah, ed., Dalit Identity and Politics (New Delhi, 2001), 62. Lack of access to land and capital means that the majority of SCs depend on manual wage labourers: in rural areas 49 per cent of SC workers were agricultural labourers in 1987-88, compared to 21 per cent among other groups, and only 22 per cent of SC workers in rural areas were self-employed cultivators, compared to 49 per cent for non-SCs: see Thorat and Deshpande Thorat, 'Caste System and Economic Inequality', 44-73 and 58-9. According to National Sample Survey figures for 1993-94,61 per cent of rural Dalit households were wage-labour households, and 70 per cent owned an acre or less of land: G. Nambissan and M. Sedwal, 'Education for All: The Situation of Dalit Children in India', in R. Govinda, ed., India Education Report: A Profile of Basic Education (New Delhi, 2002), 72-86. In 1985-86, only 8 per cent of operational holdings in Madhya Pradesh and 12 per cent in Rajasthan were held by SCs: Mendelsohn and Vicziany, The Untouchables, 156.

15. National Sample Survey figures for 1993-94, cited in Nambissan and Sedwal, 'Education for All'.

16. Sayed et al., Inclusion and Exclusion. 
asserted as part of the politics of claiming dignity. ${ }^{17}$ Having made the point of selfidentification, and the manoeuverability the identity of untouchability has provided individuals and groups, it is necessary, nonetheless, to recognise the role that the colonial state has played in validating caste through its insistence on 'codifying' Indian society.

In working with race and caste, as the discussion above hopefully makes clear, while there are significant forces at work which have the effect of stabilising the meanings (and indeed social experience) of each, there is a need to recognise their dynamic characters. Class is a major overdeterminant in each country and is responsible for investing the experience of people in their social settings with new dimensions. In response to these developments, as the discussion below on the state attempts to contextualise, are the social strategies established privileged groups devise, consciously and organically, to retain their advantage within the space for reform that the state opens up. It is to the role of the state that the discussion now turns.

\section{The Role of the State}

As has been apparent from the discussion above, both South Africa and India have had to confront complex social and colonial legacies. In each, this legacy has come to define the social character of the country: in India pervasive and internalised caste inequalities, and in South Africa deep histories of racial oppression. These legacies have manifested themselves clearly across a range of social welfare domains and, for the purposes of this discussion, markedly in education.

The scale of the legacy in each country is overwhelming. As we shall see below, in India, the social codes and the discriminations and exclusions that caste position entails exceed the protective capacity of policy and legislation. ${ }^{18}$ Similarly, 'black' and poor groups in South Africa, while theoretically enjoying the protection of a Constitution that has brought everybody within the state to the same legal standing, experience continued discrimination and marginalisation. ${ }^{19}$ The social and cultural capital that these groups have at their disposal, moreover, is not recognised in circles of power, and as a result, they struggle to access rights that have been theoretically defined as theirs for the taking.

\section{The State and Redress Policy}

In terms of its access to authority and resources, the state must be seen as the central player in both countries with respect to dealing with inclusion and

17. Ibid.

18. See S. Balagopalan and R. Subrahmanian, 'Dalit and Adivasi Children in Schools: Some Preliminary Research Themes and Findings', IDS Bulletin, 34, 1 (2003), 43-54.

19. See E.B. Fiske and H. Ladd, Elusive Equity: Education Reform in Post-Apartheid South Africa (Cape Town, 2004). 
exclusion. While it is true that the state in India and South Africa has been, like states elsewhere, subjected to a great deal of internal and external pressure, and so come to present itself as a contradictory vehicle in regard to social change, importantly, both India and South Africa have made, historically, strong commitments to broadening access and providing targeted strategies of inclusion for marginalised groups.

\begin{tabular}{|c|c|c|}
\hline & India & South Africa \\
\hline $\begin{array}{l}\text { Inheritance and } \\
\text { embedded struc- } \\
\text { tures }\end{array}$ & $\begin{array}{l}\text { - Caste } \\
\text { Indian government has } \\
\text { little control over how } \\
\text { everyday life of caste is } \\
\text { played out on ground }\end{array}$ & $\begin{array}{l}\text { - Race } \\
\text { - Embedded privilege beyond } \\
\text { school }\end{array}$ \\
\hline Policy mandates & $\begin{array}{l}\text { Activist state } \\
\text { - Constitutional and legis- } \\
\text { lative guarantees } \\
\text { Lower-caste groups de- } \\
\text { pendent on state }\end{array}$ & $\begin{array}{l}\text { - Activist state } \\
\text { - Constitutional and legislative } \\
\text { guarantees } \\
\text { Poor and black people de- } \\
\text { pendent on state }\end{array}$ \\
\hline $\begin{array}{l}\text { Structures of in- } \\
\text { clusion }\end{array}$ & $\begin{array}{l}\text { - Human Rights Commis- } \\
\text { sion (HRC) }\end{array}$ & $\begin{array}{l}\text { - HRC and other watchdog } \\
\text { bodies } \\
\text { - Not always very effective but } \\
\text { have highlighted key } \\
\text { aspects of exclusion in edu- } \\
\text { cation }\end{array}$ \\
\hline $\begin{array}{l}\text { Popular will and } \\
\text { political } \\
\text { pressures }\end{array}$ & $\begin{array}{l}\text { Strong government/state } \\
\text { political will } \\
\text { - Popular pressure for and } \\
\text { belief in the value of edu- } \\
\text { cation opportunity as a } \\
\text { means of social } \\
\text { advancement }\end{array}$ & $\begin{array}{l}\text { - Strong government political } \\
\text { will, constitutional bill of } \\
\text { rights } \\
\text { - Popular pressure for and } \\
\text { belief in the value of educa- } \\
\text { tion opportunity as a means } \\
\text { of social advancement }\end{array}$ \\
\hline $\begin{array}{l}\text { Strategies: target- } \\
\text { ing and transfers }\end{array}$ & $\begin{array}{l}\text { Strong desire among } \\
\text { Dalit and Adivasis and } \\
\text { 'black' people for educa- } \\
\text { tion } \\
\text { - Target population - Dalit } \\
\text { and Adivasi [and female] } \\
\text { learners } \\
\text { - Affirmative action }\end{array}$ & $\begin{array}{l}\text { - Target population - poor/- } \\
\text { 'black' learners } \\
\text { - Affirmative action } \\
\text { - Funding and other redress } \\
\text { mechanisms }\end{array}$ \\
\hline
\end{tabular}

Figure 1: Policy environment 
The discussion of these commitments begins with a tabular summary of the policy approaches taken in relation to the historical legacies the two countries have had to confront. Following these and included in Figure 1 are the broad policy mandates, the political climate in which the mandates have been developed (popular pressure and political will), and the forms (the mechanisms and strategies) the policies have taken. ${ }^{20}$ As Figure 1 indicates, important constitutional and other policy efforts are a key feature of India and South Africa in seeking to effect the inclusion of marginalised groups.

Both countries have what one might call activist identities. The state is configured in each country, essentially, as a rights-minded state having to address itself not simply to the protection of rights of vulnerable groups but the actual promotion of such rights. In terms of its activist orientation, the role that the state plays is both a protective one and a fundamentally overseeing one, in so far as it has constantly to be alert to the different ways in which the social structure conditions and limits the policies it makes for the protection of weak groups. The significance of the state is thus enhanced, calling for it to play a stronger role in relation to weaker groups in society. This is the first similarity shared by the two countries.

The activist state, in addition, and this is the case with both countries, is strongly ideologically marked. ${ }^{2 \mathrm{l}}$ It has to project a strong welfarist identity and it has to manage this identity in relation to three articulating pressures, namely the often prescriptive global order, the influence of local dominant groups (who often are the managers of the state), and in relation to the demands and aspirations of the weaker and more vulnerable groups within the state. It is within the social dynamics of these three pressures that the state determines a strategy for itself. Rhetorically its position places certain obligations on it, while the conjunctural circumstances it works with constantly limit how far or how deep it is able to sustain the general drift of its policies.

Symbolism plays a powerful role in each country and this is where challenges arise. ${ }^{22}$ Marginalised groups within the state, such as vulnerable lower-caste groups in India and marginalised and poor 'black' people in South Africa, do not have the means, other than through mobilising popular support, to insist on the fulfilment of their rights and are almost entirely dependent on the state for their advancement.

20. Derived from Sayed et al., Inclusion and Exclusion.

21. See R. Rajan, The Scandal of the State: Women, Law and Citizenship in Postcolonial India (Delhi, 2003), and A. Habib, J. Daniel and R. Southall, eds, The State of the Nation (Cape Town, 2003).

22. See J. Jansen, 'Explaining Non-Change in Education Reform After Apartheid: Political Symbolism and the Problem of Policy Implementation', in Y. Sayed and J. Jansen, eds, Implementing Education Policies: The South African Experience (Cape Town, 2001). 


\section{Political Will and Popular Pressure}

A distinct feature of popular political pressure in both countries is the strong desire of subordinate groups for education. While in India Dalits and Adivasis frequently choose to terminate their children's education, or tend to favour males, evident is a strong recognition of the argument that education provides opportunities for social mobility. The same desire is evident in South Africa, especially in the way in which subordinate groups, or groups with political histories make sacrifices for their children to attend good academic schools. ${ }^{23}$ Important about these desires in both countries is the alignment they enjoy with government policy. Subordinate groups in both India and South Africa agree strongly with the direction their governments are taking.

While protest in both India and South Africa remains high on the political agenda with the emergence of new social movements in South Africa and the continued mobilisation of established ones in India, and there continues to be a correspondence between the ambitions of subordinate groups and the declared agendas of the state, it remains the case that the existence of policies on paper has not translated into gains on the ground.

\section{Mechanisms and Strategies of Inclusion: Targeting and Transfers}

In India redress has been largely effected through the principle of affirmative action, while in South Africa, attempts have been made to manage redress through affirmative action which is a constitutional enactment and targeted redress in specific areas of welfare provision.

Affirmative action in both countries has been defined as a legal necessity to deal with forms of discrimination that either emanate out of formal and legalised modes of oppression and marginalisation or take their origin from social and public mores and practices that are deeply institutionalised. The point of affirmative action in these contexts is to deinstitutionalise discrimination and to replace the dominant power relations in those institutions with new legal provisions that deliberately address the barriers that prevented the subordinate groups from progressing in those societies. In South Africa affirmative action was written into the Constitution. ${ }^{24}$ Because the structural realities in the two countries have developed in different directions, and have produced distinct exclusionary outcomes, efforts to effect redress have taken different forms.

23. Sayed et al., Inclusion and Exclusion.

24. Republic of South Africa, The Constitution of the Republic of South Africa. Act 108 of 1996 (Pretoria, 1996). 


\section{The State and its Stakeholders}

Attempts to give affirmative action practical effect in South Africa have been complex and have been resisted by most privileged schools. While there have been individual schools that have explicitly committed themselves to dealing with the challenges of integration in an open-minded way, most schools have struggled to adjust to the challenge of making their staff complements and their school governing bodies more representative of the diversity of South Africa's people. ${ }^{25}$ A controversial initiative was put in place by the new government in the mid 1990s when it 'right-sized' the teacher corps in South Africa. In terms of this it lay down a pupil-teacher ratio for schools which it used to establish its funding approach. In terms of this schools, irrespective of where they were located and their past histories, would receive the same per-capita funding from the state. Its intention was to withdraw support from schools where teachers were in excess and to redeploy them to schools where there were shortages. When schools, moreover, were to make new appointments, they were required to appoint off what was called the excess list. This initiative was presented as a move to introduce equity into the system - and to affirm the needs of the poor ${ }^{26}$ The plan, however, backfired badly because, first, it had the effect of removing teachers from poor schools who had managed to increase their teacher complement, and second, critically, it was resisted by a number of better-off schools, as in the case of Grove Primary School in Cape Town, which successfully challenged the right of the Minister of Education to appoint teachers to its staff. As the Grove case illustrated, parents used the new governing body structures given to them by the state to defend narrow and often sectional interests.

In contrast to South Africa, where race forms part of the political debate (for example, the National Conference on Racism in September 2000), public policy discourses on eliminating caste-based differentiation in India with respect to access to education have been caught up in the competitive politics unleashed by affirmative action. The evolution of the present-day compensatory discrimination approach, articulated within the constitutional guarantee of equality as well as welfare targeted to the most deprived, has produced contradictory outcomes in terms of its impact on the lives of those targeted, and the extent to which it has facilitated inclusion of groups into education. Policies to make education more inclusive have focused on generating 'demand' through offering incentives such as scholarships, food rations and preferential access to higher education and public employment. They have also come to focus on making community structures

25. See C. Soudien, "Constituting the Class": An Analysis of the Process of "Integration" in South African Schools', in L. Chisholm, ed., Changing Class: Education and Social Change in PostApartheid South Africa (Cape Town, 2004).

26. See L. Chisholm, C. Soudien, S. Motala, S. Vally and D. Gilmour, 'Teachers and Structural Adjustment in South Africa', Educational Policy, 13, 3 (1999), 386-401. 
relating to schooling more representative of marginalised groups within villages, but they have, in the process, encountered significant challenges. ${ }^{27}$

Formal mechanisms have been set up to promote parent teacher interactions in Indian schools. This is discussed below, but broadly it needs to be noted here while Indian governance structures lack the formality of their South African counterparts, their intention of involving parents is similar. Significantly, however, they were found to be non-functional in most schools and communities researched. Dalit and Adivasi parents continue to feel powerless within these formal institutions, both due to the committee's limited mandate and because of existing power hierarchies in rural communities that devalue the presence of these communities in decision-making roles. Teachers continue to frame their accountability towards a monolithic educational bureaucracy rather than the local community.

Many of these problems were demonstrated in the Inexsa study reported on below.

\section{PART TWO}

\section{The Inexsa Study in South Africa and India}

The Inexsa study looked at 14 schools in three different provinces in South Africa, namely KwaZulu-Natal, the Eastern Cape and the Western Cape, and 16 field sites in two states in India, Madhya Pradesh and Rajasthan. In both countries, it is acknowledged, the sample of schools was small. However, in the context of both resource and personnel challenges in the project, care was taken to be sensitive to the racial demographic profile of South Africa and particularly to find schools in which the dimensions of race and class inclusion and exclusion could be studied. In selecting the Indian schools, considerations of the country's caste demographics were borne in mind. The project required that the school should be located in an area that had a majority Dalit or Adivasi population; the school should have adequate numbers of pupils in the class, at least 30 students; the school should have a mix of various Dalit and Adivasi jatis; and the school staff should co-operate with the research process. In both countries, finding schools that matched all of the stated criteria was difficult. Acknowledged, as a point of departure in both countries, was that it would be logistically difficult to encompass the full range of social differences represented in each, including the variety of states and provinces and their urban and rural configurations, the linguistic, cultural and ethnic differences in each and in the gender complexities that manifested themselves between and within these different locations and groups. The understanding from

27. R. Subrahmanian, 'Coproducing Universal Primary Education in a Context of Social Exclusion: Households, Community Organisations and State Administration in a District of Karnataka, India' (PhD thesis, Open University UK, 2000). 
the start of the research was to see each school as a distinct space in which the most important forms of social inclusion and exclusion for the two respective countries could be tracked. While the schools were not typical, they provided the study with an opportunity for understanding the dominant forms of exclusion playing themselves out in each country.

In South Africa the schools chosen represented the range of former apartheid education school types which had catered for different 'race' groups. The sites, therefore, included examples of African, white, coloured and Indian schools. The sites were also chosen to include a spectrum of urban, township and rural schools, and also, in the case of the African, Indian and coloured schools, examples of both poor and more financially stable communities. This latter point is important to emphasise. The researchers in the two countries looked at the micropractices of the school, in particular their admission policies, their fee structures, their language policies and classroom practices. Teachers, learners, principals and members of the community were interviewed and classrooms were observed.

It was found in the South African schools that apartheid mindsets and racialised and class-based forms of identity continue to inform people's perceptions of themselves and 'others', and significantly inform their practices and determine their institutional dynamics. Schools reached in this study were found largely to be culturally assimilationist in dealing with inclusion, demonstrating an inability of the system and the stakeholders within it to work with the complexities of difference. The study found that exclusion in South African schools was and still is achieved through the mainstreaming of dominant middle-class education. This educational experience, it is argued, is made possible by and through the development of a platform of policies that privileges particular middle-class white and English - 'Anglo' - ways of being and the displacement of vernacular languages.

Specific policies that have been developed in India with respect to improving community participation and which were employed in both Rajasthan and Madyha Pradesh include a comprehensive programme, the Sarva Shiksha Abhiyan (SSA) (or Universal Education Mission). The purpose of the SSA was to develop a wide range of educational interventions that would be appropriate for the needs of the different communities across India. ${ }^{28}$ Its focus was largely on facilitating community participation through mobilisation of disadvantaged groups in the school planning process: focusing on resource targeting, providing hostels, incentives or special facilities as required, and setting up alternative schooling facilities in unserved habitations, among others. Critical about the policy, however, and drawing attention to its limitations, is that it made little reference to the issues of education quality and discrimination with respect to Dalit and Adivasi groups.

In reviewing the policy landscape in India it is important to note that while there is awareness of the need to develop approaches that are inclusive, significant 
silences remain. While the policy attempts to devolve authority to the local level of the state, the terms of inclusion for particular groups are not specified. In the case of Adivasis there is some minor difference as compared with Dalits in policies such as the SSA - the recognition of the distinctiveness of their language and its implications for textbooks and teacher training are noted. For Dalits, however, their specific needs are lost within the generalised focus of the policy.

In making the above point, some caution needs to be exercised, because there do exist policies that move beyond the limitations outlined. In Madhya Pradesh, for example, the Education Guarantee Scheme (EGS) was developed in 1997 with the specific intention of developing a new institutional model for addressing the challenge of education for all. Central in the EGS was the recognition that out-ofschool groups continue to be overwhelmingly located in poor and unserviced villages, and at the receiving end of unequal resource distribution. The EGS drew on a sophisticated rationale: at one level, the starting point of this initiative is the recognition by the government of Madhya Pradesh that deficiencies of the public supply, rather than insufficient parental demand is the main cause of educational deprivation in the state. On the other, the diagnosis of educational problems as located largely in the social arena has led to innovations that have sought to overcome the constraints to participation on the part of disadvantaged communities.

The findings of the study in India confirmed the project's initial hypothesis, that there was much changing in Indian education, partly as a product of state action and partly as a product of general processes of social and economic change. In relation to the situation of Dalits and Adivasis, it was clear that much had changed in terms of the overt cultural exclusion of Dalit groups. But this observation had to be qualified: despite the apparent social mobility achieved by many Dalit groups, those groups which engaged in stigmatising work continued to be ostracised both in terms of the continued verbal abuse and the use of pejorative names applied to them by upper-caste teachers and members of the community; and in terms of the economic opportunities that are now somewhat more available to other Dalit groups, and not to these jatis (castes), in the main these remain fairly out of reach of most of the Dalit groups that the study researched. Cultural exclusion has thus become covert for some groups, and remains overt for those Dalit groups involved in 'stigmatising' work. Economic exclusion also persists, with the only meaningful opportunities being the few that have opened up through job reservations, either directly [and this is rare] or indirectly through networks that are opened up as a result of those who have succeeded in taking advantage of opportunities [less rare].

However, cultural exclusion persists within the classroom, as teachers respond to the expansion of schooling and the entry of children in different ways - in most cases through resenting the entry of children whose early socialisation is not considered by them as amenable to the project of modern schooling. Concerns expressed by teachers about the lack of 'cleanliness' of Dalit and Adivasi children, for instance, recalls the wide social bases of the exclusion of these groups 
based on notions of their 'ritual pollution'. Teachers' discriminatory patterns of behaviour at once reflect the wider social context, but also their own caste status and backgrounds. In reporting on this state of affairs, it is important to note that the research was conducted during the period of the Bharatiya Janata Party's (BJP) political dominance at the national level and in many states and its promotion of Hindutva - a narrow rather than an inclusive notion of what it means to be Indian. ${ }^{29}$ How this interpretation of Indianness influenced these discriminatory attitudes among the teachers and the local authorities is not clear. This reality aside, it is also the case that the lack of systemic change within the schooling system to deal with the wider conditions of schools, the overcrowding, the expansion of schooling that is taking place without clear consultation of teachers and so on has resulted in teachers' morale being very low, with consequent unfavourable implications for their relationships with lower-caste children in their schools. When frustration is taken out, it is these most vulnerable groups that bear the brunt of it. What this suggests is that the entire dynamic of widening access and introducing privileges to marginalised communities produces new oppressive responses from old power groups. Critical is recognising that choosing policy responses focused on addressing economic constraints alone without attempting to address the deeper processes of identity-based discrimination are likely to fall far short of what is required to make education for all truly meaningful as a commitment. Concerns have also been raised elsewhere and in this research about the long-term prospects of cost-cutting reforms. It may be too early to declare the impact of these initiatives as being 'disastrous' - microlevel evidence, albeit based on the very small sample of this research, suggests that communities do claim these schools as their 'own', and they have absorbed children of disadvantaged communities.

\section{Comparing School Level Practices in the Two Countries}

Beyond these broad features, the study has thrown up distinct local-level practices which demonstrate how the formally proclaimed ameliorative agenda of the state is distorted on the ground.

Figure 2 compares practice at the school level in the two countries looking at school policy, governance, access, and teaching and learning (which considers curriculum and teacher). ${ }^{30}$

29. See V. Shiva, India Divided: Diversity and Democracy Under Attack (New York, 2005), 157-9.

30. From Sayed et al., Inclusion and Exclusion. 


\begin{tabular}{|c|c|c|}
\hline Governance & $\begin{array}{l}\text { Neither country has a sin- } \\
\text { gle school practising } \\
\text { strongly inclusive gover- } \\
\text { nance practices } \\
\text { Non-functional school gov- } \\
\text { ernance in India }\end{array}$ & $\begin{array}{l}\text { Neither country has a sin- } \\
\text { gle school practising } \\
\text { strongly inclusive gover- } \\
\text { nance practices } \\
\text { Governance strong part of } \\
\text { reform agenda in SA }\end{array}$ \\
\hline Access & $\begin{array}{l}\text { Access required (proce- } \\
\text { dural access) } \\
\text { Caste single most impor- } \\
\text { tant factor for controlling } \\
\text { access in India } \\
\text { Means to administer ac- } \\
\text { cess include documenta- } \\
\text { tion, proof of residence, } \\
\text { payment of fees } \\
\text { Language, fees discrimina- } \\
\text { tory }\end{array}$ & $\begin{array}{l}\text { - Access required by law } \\
\text { (procedural access) } \\
\text { Proxies for race discrimina- } \\
\text { tion in SA include fees and } \\
\text { language use } \\
\text { - Means to administer ac- } \\
\text { cess include documenta- } \\
\text { tion, proof of residence, } \\
\text { payment of fees } \\
\text { Language, fees discrimina- } \\
\text { tory }\end{array}$ \\
\hline Curriculum & $\begin{array}{l}\text { - Traditional pedagogy in } \\
\text { India - rote learning } \\
\text { - Language major means of } \\
\text { discrimination } \\
\text { Assimilation into the domi- } \\
\text { nant cultural order preva- } \\
\text { lent } \\
\text { - Educability used to justify } \\
\text { discrimination against } \\
\text { lower-caste children in 'In- } \\
\text { dian' schools }\end{array}$ & $\begin{array}{l}\text { SA has child-centred na- } \\
\text { tional curriculum - C2005 } \\
\text { - Language major means of } \\
\text { discrimination } \\
\text { - Assimilation into the domi- } \\
\text { nant cultural order preva- } \\
\text { lent } \\
\text { - Cultivation of standards as } \\
\text { exlusionary device in SA }\end{array}$ \\
\hline Teachers & $\begin{array}{l}\text { Professional identities of } \\
\text { teachers and accountability } \\
\text { - accountability to the state } \\
\text { in India }\end{array}$ & $\begin{array}{l}\text { Professional identities of } \\
\text { teachers and accountability } \\
\text { - accountability to state } \\
\text { and parents in SA }\end{array}$ \\
\hline
\end{tabular}

Figure 2: School level practice

\section{Governance Structures}

In the area of governance, schools are located very differently within the nexus of power between community and state on the one hand, and teachers and the state on the other. Governance is a visible area of engagement in the South African situation, while it is less so for India.

The most important observation to make about the two countries here is that governance constitutes a distinct site of measurement for assessing the extent to which a school is implementing the state policy of inclusion in South Africa. In India it has not been constituted for that purpose. Significant, nonetheless, about 
this distinction is that in the one country it is a measure for facilitating inclusion while it has not explicitly been given that function in the other. Elaborating this difference, governance is therefore a distinct part of the policy machinery in South Africa, while in India it is virtually non-functional.

The presence of governance structures in the South African context notwithstanding, a second observation is that not a single school in either country can be said to be operating off strongly inclusive governance mechanisms. Neither country was able to produce a school for the study where governance deliberately set out to deal with processes of 'othering' and marginalisation. Moderate inclusive governance structures and mechanisms could be found in South Africa. For the most part, all the rest of the schools in the study were only weakly inclusive. This weak inclusiveness meant, on occasion, in both the 'Indian' and South African cases that schools did what they needed to in terms of the law, but worse, as in some South African former 'white' schools, that schools actively excluded those they did not wish to have in their governance structures. While it might be true that black parents were complicit in this process - to the extent that they preferred white teachers and parents to be in charge - the fact of the matter is that undercurrents operate which lead to exclusion.

\section{Access}

No school in South Africa is allowed to deny a child entry into a school. In India, many measures have been instituted to ensure that children have access to school. Admission requirements in the two countries are clearly stipulated by law. Critically, however, the processes of admission in the two countries are both problematic and in some respect discriminatory. While there are superficial similarities in the bureaucratic devices that are used to obstruct access, such as residential rules and documentation that has to be provided, the nature of the discrimination, however, is markedly different.

In South Africa, while there are a number of schools that provide easy access, this provision is often, for lack of a better term, procedural as opposed to deliberate. A small number of schools exist where the school has made it a policy to admit children on a first-come-first-serve basis, indiscriminately. Many schools also provide moderately easy access. A significant number of schools, however, impede access through residential requirements, language use, and critically the levying of high school fees. Language and school fees are the most egregious forms of discrimination used by schools. These, on closer inspection, are often proxy measures for race. While race, of course, is never experienced in isolation from factors such as class, it is ultimately racial discrimination that defines the exclusion experience in South Africa.

In India, access is easy in some schools, but this must be seen, as in the easy access experienced to some South African schools, as being procedural. Much more problematic, and this is the major difference between the South African and 'Indian' schools, is the difficulty that 'Indian' schools have in maintaining access. 
While children gain access, many forces conspire to push them out. Children drop out of school in large numbers. These children are invariably and predominantly lower-caste and predominantly girls. The difference between the two countries is in the in-school experience of inclusion. In the South African case, in the most exclusionary schools, children are kept out before they can enter, while in India, they are gradually pushed out.

\section{Curriculum}

In South Africa a national curriculum has been adopted - Curriculum 2005 (recently revised) - which is deliberately child-centred. Schools are allowed to infuse independent elements into the curriculum but have to deliver these according to guidelines provided by the national department. The broad approach of the curriculum is what sets it apart from India. While the curriculum in India, for the most part, is structured around traditional pedagogical approaches, such as memorisation, South Africa has moved towards a competency-based approach. This difference sets up the context for the two countries as completely different learning spaces.

Within these spaces, and out of this difference, however, similar exclusionary experiences are being felt. Language is used as a critical means of exclusion. In South Africa, exclusion is experienced in the almost blanket denial of access to mother-tongue learning. Similar experiences were recorded in India where children were forced to learn Hindi at the expense of their mother tongues. Structural exclusion, as a result, is experienced at the heart of the formal curriculum.

In terms of the formal curriculum the 'Indian' schools in the study provide examples of curricular approaches that are severely exclusionary. No schools were found that one could describe as providing strongly inclusive pedagogical approaches. Only one school had teachers who were managing their teaching in moderately inclusive ways. South Africa, on the other hand, had a number of schools where the curriculum could be described as moderately inclusive.

Not unexpectedly, there are many differences in the informal curricula of 'Indian' and South African schools. In the 'Indian' schools of the study, the most potent mechanism used by schools to shape the school ethos and climate was the notion of educability. In the South African context, the corresponding device was the invocation of standards by parents through their teachers and their school governing bodies.

Educability - essentially a notion describing learning potential - is the most important means at the disposal of 'Indian' teachers to manage their relationships with children and their parents. In the discourse of educability in India, lower-caste children are habitually described as 'ineducable'. Features of their home background and their caste status are naturalised as attributes that belong - 
sometimes congenitally - to lower-caste groups. This discourse is used to justify the discriminatory treatment teachers mete out to their learners. ${ }^{31}$

In the South African context, the ethos of school is fundamentally maintained through the invocation of standards. Standards are invoked to discipline behaviour and govern relationships of parents with schools. Central are rules of deportment, language use, and responsibilities that parents - invariably heavily gendered middle-class mothers - are expected to display and reproduce. The effect is to exclude groups that do not have the social and cultural capital privileged by the school.

In both the 'Indian' and South African cases, educability and the maintenance of standards are moments, and indeed sites, for the perpetuation of dominance and the mobilisation of hegemonic values. In both sites, the weak and the vulnerable are expected to assimilate into the hegemonic order. The dominant values, norms and beliefs of the school are assumed to be those that African, Dalit and Adivasi students need to adapt to and adopt. The ethos of the school is what African, Dalit and Adivasi students need to be inserted into, it is what they need to be assimilated into.

\section{Teachers}

A difference in experience in the two countries arises out of the professional identities structured for teachers in the two countries. While accountability in South Africa pivots between accounting to parents and the state, in India, teachers demonstrate, at least in the schools in the study, little accountability to their children. The study yielded many examples of teachers only teaching for a small number of periods a day, teaching in ways that discouraged children's curiosity for learning and regularly physically abusing children in the classes. These conditions in the classroom were responsible for the high push-out rate of learners.

At the core of the accountability matter are teachers' understanding of what their professional obligations are. Strong racially defined differences exist among South African teachers regarding their responsibilities. Teachers in 'black' communities tend to cede their professional initiative to the state, while teachers in white communities guard their independence from the state. This contrasts with the situation in India where teachers' caste identities strongly influence how they manage their professional identities.

\section{CONCLUSION}

This article has sought to highlight the differences and similarities between India and South Africa in tackling exclusion. What is important to note is that while both

31. For a full discussion of this, see S. Balagopalan, "Neither Suited for the Home nor for the Fields": Inclusion, Formal Schooling and the Adivasi Child', IDS Bulletin, 34, 1 (2003), 55-62. 
countries have made inclusion a defining feature of their reform agendas, both continue to struggle with the key issues of race and caste. Neither country, significantly, has been able to reach the point where the problems around these key issues have been substantially removed.

In developing an explanation for why these challenges persist one has to be careful in a preliminary study such as this. Clearly, much more work - of whatever kind, qualitative and quantitative - is required to understand how domination is produced and reproduced. Preliminarily, it is clear that structural factors continue to determine the nature of the everyday world in both countries. Poverty, on its own, is a conditioning factor in the material access marginalised groups have to resources in India. The physical expansion of schooling facilities, for example, suggests how much ground needs to be made up in the financing of and appointment of additional teachers and the delivery of materials in these schools. While no South African school can deny any child access, it remains true that children still need to reach these schools from wherever they might be. Poverty determines how easily they can access the rights made available in terms of the new legislation.

Much more significant in each country is the deliberate distortion that dominant groups are able to make to the reform policy. Language rights in both India and South Africa, the use of fees in South Africa, the hegemony of the standards discourse in South Africa and its malicious analogue in India - the notion of ineducability - speak to the powerful ways in which the privileged continue to be able to reconfigure the system for their own advantage.

In South Africa, this advantage proceeds directly from the way in which the existing policy sits within the organisational and administrative framework of decentralisation. What decentralisation does is formally extend and deepen democracy. It theoretically devolves power and decision-making to the lowest levels of authority. In South Africa, however, all these lower levels continue to be configured in the image of the country's social hierarchy. This is particularly the case for school governing bodies that have been empowered to make decisions that earlier (ironically, in pre-democracy times) was the preserve of higher levels of government (provincial and central government). In devolving power to school governing bodies, without deracialising them, the state has effectively ceded its advantage. One is seeing therefore, in the South African state, decision-making groups at work that are, predictably, acting, and let it be said, lawfully so, in what they think their own groups' best interests might be. The findings of the Inexsa study show how school governing bodies are able to exclude children entirely legally.

In India, the situation is characterised by different dynamics. There it is less the case of the policy being used in self-interested ways, but more the case of the policy being inserted into weakly monitored and weakly framed environments. While policy for inclusion exists, it is not able to be implemented. Important about these environments is that none of the mandates come with sanctions. The inducements that have been put in place require the marginalised groups to exercise 
agency - they respond to inducements to move out of their states of disadvantage - but they have no social or political authority to uphold their rights. They confront all the social norms in the schools which are strongly practised and enforced outside of them. Caste, as a consequence, stringently conditions and is rarely absent from the experience of the teacher-pupil relationship. Dalits and Adivasis, as a consequence, enjoy little protection from the state when the broader social values and mores determine the character of the school and effectively come to reproduce the disadvantage they experience outside of school. Symptomatic of this is the ubiquitous name-calling and humiliation that children experience on a daily basis. Their ability to activate their rights is thus constrained.

We see thus social advantage reproduced through the paradoxical office of the law in South Africa and through the ambience of custom in India. Both countries have policies that speak to their inherited inequalities. In neither has inequality been broken. Dominant groups in both countries exercise a strong hold over the mediation of the reform project. They do it differently, however. In one with the backing of the law, in the other in defiance of it, one sees the reproduction of privilege and subordination. In India, one is confronted with, essentially, the challenge of disentangling the deeply embedded social codes and habits that define caste from what are perceived to be their religious moorings. In South Africa, the challenge is embodied in the inability of groups to overcome their own histories and to use the available ameliorative framework for ends greater than their own. 